\title{
EXPERIMENTAL AND COMPUTER RESEARCHES OF HOLLOW-CORE SLABS OSCILLATIONS
}

\author{
${ }^{1}$ Surianinov M., Dr.Tech.Sc., Professor, \\ sng@ogasa.org.ua, ORCID: 0000-0003-2592-5221 \\ ${ }^{1}$ Makovkina T., graduate student, \\ tmakovkina@icloud.com, ORCID: 0000-0002-2628-5724 \\ ${ }^{1}$ Chuchmai O., $\mathrm{PhD}$, Senior Lecturer, \\ alexsandrch14061983@gmail.com, ORCID: 0000-0002-5856-623X \\ ${ }^{1}$ Odesa State Academy of Civil Engineering and Architecture \\ 4, Didrikhson street, Odessa, 65029, Ukraine
}

\begin{abstract}
The results of a free oscillations study of a reinforced concrete slab model, the prototype of which is a floor slab PK 30.12-8, manufactured at the enterprise LLC Velikodolinsky $\mathrm{R} / \mathrm{CC}$ Plant, are presented. A stand for dynamic tests was developed, the testing of which was performed on a metal I-beam. For numerical analysis by the finite element method, engineering programs for calculating SCAD, ANSYS, and LIRA-CAD software were used. As a result of preliminary static tests, it was found that the cracking process in the slabs begins at the seventh stage of loading, with a load of $16.6 \mathrm{kN}$, which is approximately 0.6 of the actual breaking load $F_{u l t}$. In this regard, when determining the frequencies and forms of free oscillations, the authors proceed from the fact that deformation is elastic in nature not only in the absence of an external static load, but also when it changes in the range from 0 to 0.5 from the actual breaking load.

With the onset of cracking, deformation becomes non-linear, and the modulus of elasticity of the material changes significantly. Based on these considerations, the frequencies of free vibrations were experimentally determined in the absence of an external load and the initial modulus of elasticity of the material, and then with a constant static load varying in the interval $(0,5 \div 0,9) F_{u l t}$ with the step of $0.1 F_{u l t}$ with the corresponding values of the modulus of elasticity determined during static tests.

The results of the experimental determination of the first five natural frequencies and their calculation in SCAD, ANSYS and LIRA-CAD are presented. An analysis of the obtained values shows good comparability of the experimental and calculated data. ANSYS and PC LIRA-SAPR give almost the same results, while the results of calculations in SCAD differ from them by 1.5-3\%. At the same time, the frequency spectrum calculated in SCAD is lower than in the other two programs. The experimentally obtained frequency values were higher than in numerical simulation. Regardless of the deformation nature, the smallest discrepancy between the experimental and numerical values is observed for the lowest vibration frequency (within 6.5\%). For other spectrum frequencies, this discrepancy averages $10-10.5 \%$.
\end{abstract}

Keywords: slab, free oscillations, frequency spectrum, dynamic model, reinforced concrete, SCAD, ANSYS, PC LIRA-SAPR.

Introduction. The behavior of reinforced concrete slabs under the static action of external loads has been studied in a large number of both theoretical and experimental works of domestic and foreign scientists [1-5]. The issues of slab dynamics, however, as well as of other reinforced concrete structures, are much less studied [6-10].

This situation, apparently, is explained by the fact that dynamic calculations of reinforced concrete structures are associated with solving a whole range of issues: determination of dynamic load parameters; limit states and methods of their normalization; accounting for changes in the strength and deformation characteristics of concrete and reinforcement; determination of forces in structures, etc. A significant contribution to the dynamic parameters of reinforced concrete 
structures is made by the nature of reinforcement. This fact is well known, but has not yet been thoroughly studied, either quantitatively or qualitatively.

Some authors state, for example, that the real contribution of reinforced concrete beams strengthening is several times greater than the contribution obtained by calculations using existing theoretical methods [11]. And the effect of dispersed reinforcement, in particular, steel fiber, on the dynamic parameters has been studied even less.

Problem formulation. When solving almost any dynamic problem, it becomes necessary to determine the natural frequencies and oscillation modes, which is natural, since these parameters determine the behavior of the system under other types of dynamic effects. As applied to plates and slabs, this problem has an analytical solution for the Levy boundary conditions [12] and a numerical-analytical solution for any boundary conditions [13]. However, in these works we are talking about isotropic plates, without taking into account the specifics of reinforced concrete, the presence of reinforcement, voids in the plates, additional dispersed reinforcement, etc.

The aim of this work is experimental and numerical determination of natural frequencies and waveforms of reinforced concrete slabs.

Research Methodology. To conduct the experiment, the authors developed a test bench, the design and capabilities of which are given in our previous works [14, 15]. The first three frequencies of free vibrations are determined. For numerical analysis by the finite element method, engineering programs for calculating SCAD, ANSYS, and LIRA-CAD software were used.

Research results. A series of models of a hollow core slab was made (Fig. 1) with bar reinforcement strengthening (A III). At the same time, cubic samples of $100 \times 100 \times 100 \mathrm{~mm}$ were prepared for research from concrete of the same batch, which were tested for compression to failure, which made it possible to establish the class of concrete $(\mathrm{C} 16 / 20)$ in accordance with the standards (coarse aggregate fraction less than $10 \mathrm{~mm}$ ). The geometric dimensions of the model are halved in relation to the dimensions of the serial plate. At the same time, for technological reasons (fiber dimensions: further studies of plates with additional reinforcement with steel fiber with the same number of bar reinforcement are planned), model plates have 5 voids, and not 6 , as in serial plates.



Fig. 1. Hollow-core reinforced concrete floor slab model

Static tests of model reinforced concrete slabs were carried out on a specially mounted stand. The loading scheme is shown in Fig. 2. During these tests, the load was applied in steps of $10 \%$ of the estimated ultimate load. 


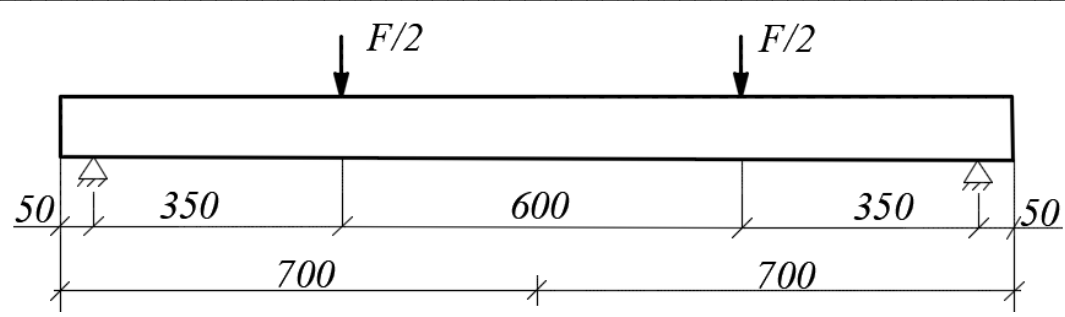

Fig. 2. Loading scheme

In classical dynamics, it is shown that the form of the differential equation of free oscillations under the action of constant forces on the system will be the same as in the absence of them if the body displacement is counted from the position of its static equilibrium [12]. This means that in the field of elastic deformations, the natural frequency does not depend on the external static load on the structure. As a result of static tests, it was found that the cracking process in the plates begins at the seventh stage of loading, with a load of $16.6 \mathrm{kN}$. Here, the cracking moment of $2.94 \mathrm{kNm}$ was recorded, the same for all tested plates. The breaking load was $27.9 \mathrm{kN}$ at the seventh stage of loading at a moment of 15.41 $\mathrm{kNm}$. Thus, the load at the beginning of crack formation is approximately 0.6 of the actual ultimate load $F_{u l t}$. Therefore, when determining the frequencies and forms of free vibrations of a reinforced concrete slab, one can proceed from the fact that deformation is elastic in nature not only in the absence of an external static load, but also when it changes in the range from 0 to 0.5 from the actual breaking load. Visualization of the experiment first stage results when determining the lowest oscillation frequency is shown in Fig. 3, 4.



Fig. 3. Determination of frequencies on a test bench $M O D A L-2$ 


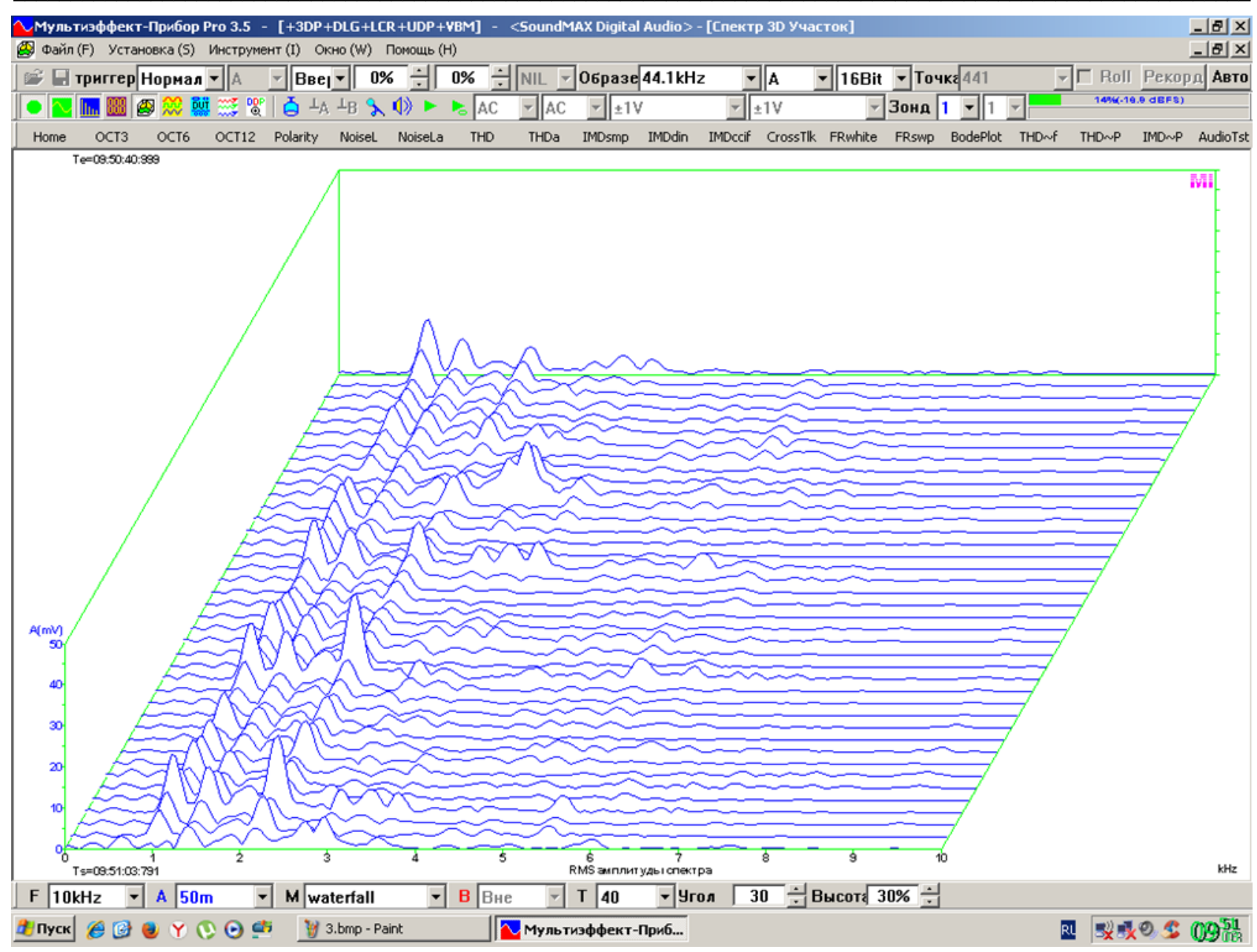

Fig. 4. Amplitudes of vibrations in a three-dimensional image

With the onset of cracking, deformation becomes non-linear, and the modulus of elasticity changes significantly. Based on these considerations, the frequencies of free vibrations at the first stage were experimentally determined in the absence of an external load and the initial modulus of the material elasticity, and then with a constant static load that varies in the interval $(0,5 \div 0,9) F_{u l t}$ with the step of $0.1 F_{u l t}$ with the corresponding values of the elastic modulus determined in the course of static tests.

Table 1 shows the numerical values of the five natural frequencies determined experimentally and based on computer simulation. And the corresponding waveforms are shown in Fig. 5 (4 forms shown). The discrepancy in the Table 1 was determined by comparing experimental data and calculation results in ANSYS.

Table 1 - Eigenfrequencies $\left(\mathrm{s}^{-1}\right)$ at elastic deformation

\begin{tabular}{|c|c|c|c|c|c|}
\hline Frequencies & Experiment & ANSYS & LIRA-SAPR & SCAD & $\begin{array}{c}\text { Discrepancy, \% } \\
\text { Experiment } \leftrightarrow \text { ANSYS }\end{array}$ \\
\hline 1 & 736,2 & 690,5 & 688,0 & 643,2 & 6,21 \\
\hline 2 & 2118,0 & 1917,9 & 1915,6 & 1791,5 & 9,45 \\
\hline 3 & 2814,4 & 2528,0 & 2523,8 & 2359,3 & 10,18 \\
\hline 4 & 3165,4 & 2836,5 & 2831,7 & 2647,5 & 10,39 \\
\hline 5 & 4281,6 & 3864,5 & 3854,4 & 3613,8 & 9,74 \\
\hline
\end{tabular}



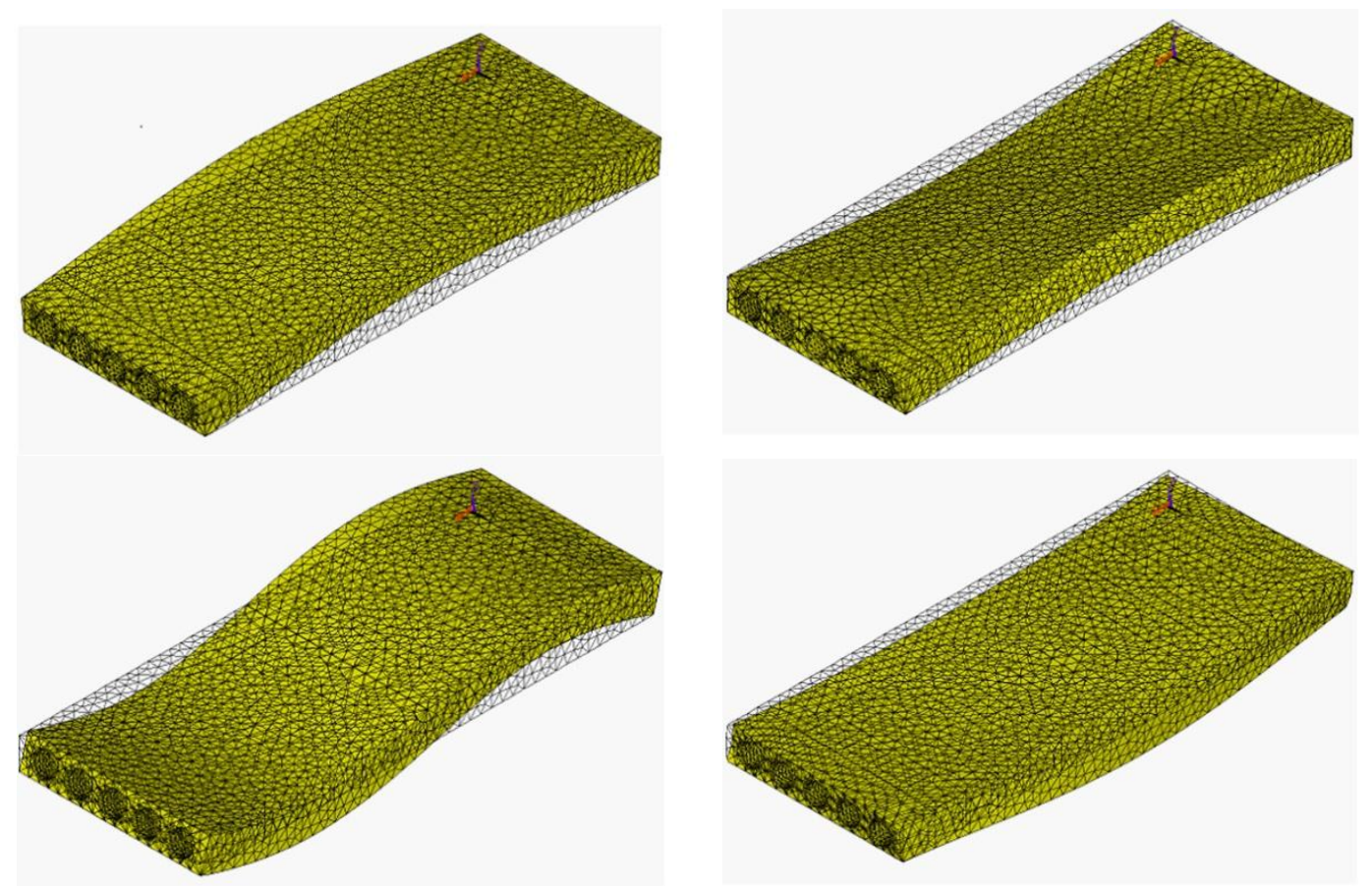

Fig. 5. Waveforms

The results of tests and computer simulations at the second stage - at a constant static load that varies in the interval $(0,5 \div 0,9) F_{u l t}$ with a step of $0.1 F_{u l t}$ for the corresponding values of the elastic modulus determined during static tests - are given in Table 2.

Table 2 - Natural frequencies $\left(\mathrm{s}^{-1}\right)$ at inelastic deformation

\begin{tabular}{|c|c|c|c|c|c|c|}
\hline Static load & Frequencies & Experiment & ANSYS & LIRA-SAPR & SCAD & $\begin{array}{c}\text { Discrepancy, \% } \\
\text { Experiment } \leftrightarrow \text { ANSYS }\end{array}$ \\
\hline \multirow{5}{*}{$0,6 F_{u l t}$} & 1 & 648,4 & 608,4 & 607,9 & 596,4 & 6,17 \\
\hline & 2 & 1889,3 & 1694,7 & 1692,8 & 1658,8 & 10,30 \\
\hline & 3 & 2475,3 & 2231,8 & 2230,2 & 2177,4 & 9,84 \\
\hline & 4 & 2789,1 & 2504,5 & 2502,3 & 2436,9 & 10,20 \\
\hline & 5 & 3801,4 & 3418,6 & 3405,6 & 3292,4 & 10,07 \\
\hline \multirow{5}{*}{$0,7 F_{u l t}$} & 1 & 430,8 & 403,6 & 403,3 & 390,8 & 6,31 \\
\hline & 2 & 1250,1 & 1124,1 & 1123,1 & 1098,0 & 10,08 \\
\hline & 3 & 1640,0 & 1480,6 & 1479,7 & 1423,1 & 9,72 \\
\hline & 4 & 1850,9 & 1661,3 & 1660,2 & 1597,3 & 10,24 \\
\hline & 5 & 2523,6 & 2267,7 & 2259,8 & 2171,8 & 10,14 \\
\hline \multirow{5}{*}{$0,8 F_{u l t}$} & 1 & 368,0 & 344,2 & 343,9 & 334,4 & 6,47 \\
\hline & 2 & 1068,7 & 958,7 & 957,7 & 939,8 & 10,29 \\
\hline & 3 & 1407,3 & 1262,5 & 1261,7 & 1230,3 & 10,29 \\
\hline & 4 & 1579,1 & 1416,7 & 1415,6 & 1372,0 & 10,28 \\
\hline & 5 & 2155,9 & 1933,9 & 1930,9 & 1864,1 & 10,30 \\
\hline \multirow{5}{*}{$0,9 F_{u l t}$} & 1 & 225,4 & 210,8 & 210,6 & 204,3 & 6,48 \\
\hline & 2 & 654,1 & 587,1 & 586,4 & 567,6 & 10,24 \\
\hline & 3 & 860,8 & 773,1 & 772,6 & 747,5 & 10,19 \\
\hline & 4 & 967,4 & 867,6 & 866,8 & 829,2 & 10,32 \\
\hline & 5 & 1321,1 & 1184,2 & 1180,0 & 1135,9 & 10,36 \\
\hline
\end{tabular}


Conclusions. An analysis of the results indicates that it is advisable to use ANSYS or LIRACAD software for computer simulation of the task, which give almost the same results, while the results of calculations in SCAD differ from them, although insignificantly (by 1.5-3\%) At the same time, the frequency spectrum calculated in SCAD is lower than in the other two programs. The experimentally obtained frequency values, on the contrary, turned out to be higher than with numerical simulation. As can be seen from the Table 1 and Table 2, regardless of the deformation nature, the smallest discrepancy between the experimental and numerical values is observed for the lowest vibration frequency (within 6.5\%). For other spectrum frequencies, this discrepancy averages $10-10.5 \%$.

\section{References}

[1] A.B. Golyshev, V.Ya. Bachinskij, V.P. Polishuk, A.V. Harchenko, I.V. Rudenko, Proektirovanie zhelezobetonnyh konstrukcij. Spravochnoe posobie. M.: Izd-vo ASV, 1990.

[2] A.V. Borovskih, Raschyoty zhelezobetonnyh konstrukcij po predelnym sostoyaniyam $i$ predelnomu ravnovesiyu. M.: Izd-vo ASV, 2004.

[3] David Fanella, Reinforced concrete structures: analysis and design. Second Edition. New York, 2015.

[4] V.M. Karpyuk, A.I. Kostyuk, Yu.A. Semina, "General case of nonlinear deformationstrength model of reinforced concrete structures", Strength of Materials, USA, vol. 50, Issue 3, pp. 453-464, 2018.

[5] Matija Orešković, Aleksej Aniskin, Yevgenii Klymenko, Goran Kozina, "Analysis of damaged concrete columns of circular cross-section", Technical gazette, vol. 25, no. 2, pp. 337-343, 2018.

[6] V.I. Korobko, A.V. Korobko, Stroitelnaya mehanika: dinamika i ustojchivost sterzhnevyh sistem. M.: Izd-vo ASV, 2008.

[7] O.G. Kumpyak, D.G. Kopanica, Prochnost i deformativnost zhelezobetonnyh sooruzhenij pri kratkovremennom dinamicheskom nagruzhenii. Tomsk: Izd-vo STT, 2002.

[8] Manuel Miranda, Dynamic behavior of reinforced concrete. London, 2011.

[9] A.M., Maslennikov, R.O Onchiri, "Kolebaniya zhelezobetonnoj balki pri nalichii treshin", Izvestiya OrelGTU Nauchnyj zhurnal, no. 2/14(530), pp. 83 - 85, 2007.

[10] Z.R. Galyautdinov, "Raschyot zhelezobetonnyh plit na kratkovremennye dinamicheskie nagruzki s uchyotom poyavleniya i razvitiya treshin", Problemy razvitiya teorii sooruzhenij i sovershenstvovaniya stroitelnyh konstrukci, Tomsk, pp. 52 - 53, 2002.

[11] M.V. Milov, G.M. Nigmetov, R.A. Sidorets, "Assessment of reinforcement and residual life of a reinforced concrete beam according to its dynamic parameters", International journal of applied and fundamental research, vol. 2, pp. $24-40,2016$.

[12] I.M. Babakov, Teoriya kolebanij. 4-e izd., ispr. M.: Drofa, 2004.

[13] A.F. Dashenko, L.V. Kolomiec, V.F. Orobej, N.G. Suryaninov, Chislenno-analiticheskij metod granichnyh elementov, Odessa: VMV, vol. 2, T.1, T.2, 2010.

[14] M.G. Sur'yaninov, T.S. Makovkina, "Analitichni i eksperimentalni doslidzhennya vilnih kolivan stalefibrobetonnih balok", Naukovi Notatki, Luck, vol. 66, pp. 351-355, 2019.

[15] N.G. Suryaninov, T.S. Makovkina, "Eksperimentalnye issledovaniya svobodnyh kolebanij zhelezobetonnyh i fibrobetonnyh balok", Visnik ODABA, vol. 74, pp. 75-81, 2019.

[16] N.N. Fedorova, S.A. Valger, M.N. Danilov, Yu.V. Zaharova, Osnovy raboty v ANSYS 17. M.: DMK Press, 2017. 


\title{
ЕКСПЕРИМЕНТАЛЬНІ І КОМП'ЮТЕРНІ ДОСЛІДЖЕННЯ КОЛИВАНЬ ПУСТОТНИХ ПЛИТ
}

\author{
${ }^{1}$ Сур'янінов М.Г., д.т.н., професор, \\ sng@ogasa.org.ua, ORCID: 0000-0003-2592-5221 \\ ${ }^{1}$ Маковкіна Т.С., аспірант, \\ tmakovkina@icloud.com, ORCID: 0000-0002-2628-5724, \\ ${ }^{1}$ Чучмай О.М., к.т.н., ст. викладач, \\ alexsandrch14061983@gmail.com, ORCID: 0000-0002-5856-623X \\ ${ }^{1}$ Одеська державна академія будівниитва та архітектури \\ вул. Дідріхсона, 4, м. Одеса, 65029, Україна
}

\begin{abstract}
Анотація. Наведено результати дослідження вільних коливань моделі залізобетонної плити, прообразом якої є плита перекриття ПК 30.12-8, що випускається на підприємстві ТОВ «Великодолинський завод ЗБК». Розроблено стенд для динамічних випробувань, тестування якого виконано на металевій двотавровій балці. Для чисельного аналізу методом скінчених елементів використані інженерні програми розрахунку SCAD, ANSYS і ПК ЛIPAСАПР. В результаті попередніх статичних випробувань встановлено, що процес утворення тріщин в плитах починається на сьомій ступені навантажування, при навантаженні 16,6 кН, що становить приблизно 0,6 від фактичної величини руйнівного навантаження $F_{u l t}$.У зв'язку 3 цим при визначенні частот і форм вільних коливань автори виходять 3 того, що деформування носить пружний характер не тільки в відсутність зовнішнього статичного навантаження, але і при його зміні в інтервалі від 0 до 0,5 від фактичного, що руйнує плиту.

3 початком утворення тріщин деформування стає нелінійним, при цьому істотно змінюється модуль пружності матеріалу. Виходячи 3 цих міркувань, частоти вільних коливань були експериментально визначені при відсутності зовнішнього навантаження i початковому модулі пружності матеріалу, а потім - при постійному статичному навантаженні, що змінюється в інтервалі $(0,5 \div 0,9) F_{u l t} 3$ кроком $0,1 F_{u l t}$ при відповідних величинах модуля пружності, визначених у ході статичних випробувань.

Наведено результати експериментального визначення п'яти перших власних частот і їх обчислення в SCAD, ANSYS і ПК ЛIPA-CAПР. Аналіз отриманих значень показує хорошу сумісність експериментальних і розрахункових даних. ANSYS і ПК ЛІРА-САПР дають практично однакові результати, в той час як результати розрахунків в SCAD відрізняються від них на 1,5-3\%. При цьому спектр частот, розрахований в SCAD, виявляється нижче, ніж в двох інших програмах. Експериментально отримані значення частот виявилися вищими, ніж при чисельному моделюванні. Незалежно від характеру деформування, найменше розбіжність між експериментальними і чисельними величинами спостерігається для нижчої частоти коливань (в межах 6,5\%). Для інших частот спектра це розбіжність в середньому становить $10-10,5 \%$.
\end{abstract}

Ключові слова: плита, вільні коливання, спектр частот, експеримент, динамічна модель, залізобетон, SCAD, ANSYS і ПК ЛIPA-САПР. 


\title{
ЭКСПЕРИМЕНТАЛЬНЫЕ И КОМПЬЮТЕРНЫЕ ИССЛЕДОВАНИЯ КОЛЕБАНИЙ ПУСТОТНЫХ ПЛИТ
}

\author{
${ }^{1}$ Сурьянинов Н.Г., Д.Т.н., профессор, \\ sng@ogasa.org.ua, ORCID: 0000-0003-2592-5221 \\ ${ }^{1}$ Маковкина Т.C., аспирант, \\ tmakovkina@icloud.com, ORCID: 0000-0002-2628-5724 \\ ${ }^{1}$ Чучмай А.M., к.т.н., ст. преподаватель, \\ alexsandrch14061983@gmail.com, ORCID: 0000-0002-5856-623X \\ ${ }^{1}$ Одесская государственная академия строительства и архитектурь \\ ул. Дидрихсона, 4, г. Одесса, 65029, Украина
}

Аннотация. Приведены результаты исследования свободных колебаний модели железобетонной плиты, прообразом которой является плита перекрытия ПК 30.12-8, выпускаемая на предприятии ООО «Великодолинский завод ЖБК». Разработан стенд для динамических испытаний, тестирование которого выполнено на металлической двутавровой балке. Для численного анализа методом конечных элементов использованы инженерные программы расчета SCAD, ANSYS и ПК ЛИРА-САПР. В результате предварительных статических испытаний установлено, что процесс трещинообразования в плитах начинается на седьмой ступени нагружения, при нагрузке 16,6 кН, что составляет примерно 0,6 от фактической разрушающей нагрузки $F_{u l t}$. В связи с этим при определении частот и форм свободных колебаний авторы исходят из того, что деформирование носит упругий характер не только в отсутствие внешней статической нагрузки, но и при ее изменении в интервале от 0 до 0,5 от фактической разрушающей.

С началом образования трещин деформирование становится нелинейным, при этом существенно изменяется модуль упругости материала. Исходя из этих соображений, частоты свободных колебаний были экспериментально определены при отсутствии внешней нагрузки и начальном модуле упругости материала, а затем - при постоянной статической нагрузке, изменяющейся в интервале $(0,5 \div 0,9) F_{u l t}$ с шагом $0,1 F_{u l t}$ при соответствующих величинах модуля упругости, определенных в ходе статических испытаний.

Приведены результаты экспериментального определения пяти первых собственных частот и их вычисления в SCAD, ANSYS и ПК ЛИРА-САПР. Анализ полученных значений показывает хорошую сопоставимость экспериментальных и расчетных данных. ANSYS и ПК ЛИРА-САПР дают практически одинаковые результаты, в то время как результаты расчетов в SCAD отличаются от них на 1,5-3 \%. При этом спектр частот, рассчитанный в SCAD, оказывается ниже, чем в двух других программах. Экспериментально полученные значения частот оказались выше, чем при численном моделировании. Независимо от характера деформирования, наименьшее расхождение между экспериментальными и численными величинами наблюдается для низшей частоты колебаний (в пределах 6,5%). Для других частот спектра это расхождение в среднем составляет 10-10,5\%.

Ключевые слова: плита, свободные колебания, спектр частот, эксперимент, динамическая модель, железобетон, SCAD, ANSYS и ПК ЛИРА-САПР.

Стаття надійшла до редакції 6.02.2020 